\author{
ACTA MYCOLOGICA \\ Vol. 47 (2): 191-202 \\ 2012
}

\title{
The occurrence of entomopathogenic fungi in soils from mid-field woodlots and adjacent small-scale arable fields
}

\author{
CEZARY TKACZUK ${ }^{1}$, TOMASZ KRZYCZKOWSKI ${ }^{1}$ and RUDOLF WEGENSTEINER ${ }^{2}$ \\ ${ }^{1}$ Siedlce University of Natural Sciences and Humanities \\ Department of Plant Protection, Prusa 14, PL-08-110 Siedlce; tkaczuk@uph.edu.pl \\ ${ }^{2}$ University of Natural Resources and Life Sciences, Department of Forest and Soil Sciences \\ Georg Mendel Str. 33, A-1180 Vienna, rudolf.wegensteiner@boku.ac.at
}

Tkaczuk C., Krzyczkowski T., Wegensteiner R.: The occurrence of entomopathogenic fungi in soils from mid-field woodlots and adjacent small-scale arable fields. Acta Mycol. 47 (2): 191-202, 2012.

The aim of this study was to compare the species composition and the intensity of entomopathogenic fungi occurrence in the soil from mid-field woodlots and adjacent small farmlands. The study material consisted of soil samples taken from a mid-field woodlot and an adjacent small-scale arable field in three different localities in the vicinity of Siedlce. Entomopathogenic fungi were isolated from soil using two methods: the insect bait method and the selective medium. The comparative study showed that the soil from mid-field woodlots was characterized by a richer species composition of entomopathogenic fungi than of adjacent arable fields. A total of six fungal species representing the anamorphs of Hypocreales (Ascomycota) were isolated from the soil collected from mid-field woodlots: B. bassiana, B. brongniartii, M. anisopliae, M. flavoviride, I. farinosa and I. fumosorosea. The presence of only three species was reported in the farmland soil: B. bassiana, M. anisopliae and I. fumosorosea. This fact confirms the important role of semi-natural habitats as a source of biodiversity of entomopathogenic fungi in agricultural landscape. It was found that entomopathogenic fungi together formed more colony-forming units in the soil from arable fields than that of neighbouring mid-field woodlots. B. bassiana was the species of fungus which infected more bait insect larvae and formed significantly more colony-forming units (CFU) in the soil from mid-field woodlots than that of farmland in the localities studied, whereas the trend was the opposite in the case of I. fumosorosea and M. anisopliae. Given the presence of entomopathogenic fungi in the farmland soil in the three test places together, it was found that $I$. fumosorosea was dominant in the soil from the two arable fields, where this fungus infected more G. mellonella larvae and formed significantly more CFUs than the other species of fungi. M. anisopliae was the second most frequently isolated farmland species.

Key words: insect-pathogenic fungi, Hypocreales, (Ascomycota) anamorphs, soil, agricultural landscape 


\section{INTRODUCTION}

Fungi are the largest group of microorganisms colonizing the soil environment after bacteria. Among them are entomopathogenic species which play an important role as one of the natural factors limiting populations of typical soil insect pests that overwinter or pupate in the soil environment (Ignoffo et al. 1978; Ferron 1981; Miętkiewski et al. 1994; Bajan et al. 1995). It is estimated that about $90 \%$ of arthropods harmful to plants spend at least part of their life cycle in soil (Gaugler 1988). Specimens which have died in soil as a result of mycoses spread diseases in the soil environment. The occurrence, development and pathogenicity of entomopathogenic fungi in soil are conditioned by a number of biotic and abiotic factors in the environment, as well as the agricultural and non-agricultural human activity.

Arthropods play a very important role among the biotic factors, as being potential hosts for these fungi, they determine their occurrence and survival in soil. The commonly accepted belief is that farmers affecting the physical and chemical properties of the environment, transforming the structure of vegetation both in fields and landscapes, contribute to the depletion of biological resources (Ryszkowski 1985; Karg 1989; Ryszkowski, Karg 1991). Issues related to the protection of biodiversity in rural areas are among the most important priorities set by the European Union in matters relating to environmental protection. Agri-environment schemes are an essential tool for the protection of valuable natural habitats associated with agricultural landscape. In this landscape, farmland are surrounded by semi-natural habitats such as mid-field woodlots and field margins which are specific refugia for flora and fauna not present in arable fields (Marshall, Moonen 2002; Meyling 2005). These habitats are the ideal place for many wintering arthropod species whose rich communities in turn determine a large variety and ease of propagation of pathogens, including entomopathogenic fungi. Therefore, unfarmed parts of natural vegetation clusters marginal among arable fields, water tanks and trees introduced in strips or on small areas of land become very important for the preservation of the biotic assemblages. While the botanical, avifaunistic and entomological characteristics of such structural elements of agricultural landscapes are relatively well developed, data relating to entomopathogens that are contained therein are quite sporadic (Bałazy, Cysewski 2003; Bałazy 2007). It is known, however, that the species composition of entomopathogenic fungi in semi-natural habitat soils, i.e. excluded from agrotechnical pressure, is different from that observed in soils intensively used for agriculture (Steenberg 1995; Bidochka et al. 1998; Klingen et al. 2002; Meiling, Eilenberg 2006; Tkaczuk 2008).

The aim of this study was to compare the species composition and the intensity of entomopathogenic fungi occurrence in the soil from mid-field woodlots and adjacent small farmlands. 


\section{MATERIAL AND METHODS}

Sampling and characterization of soil samples. The study material consisted of soil samples taken at the beginning of December 2006 in three localities in the vicinity of Siedlce: Purzec, Borki Siedleckie and Pruszyn. In each place soil samples were collected from two environments: a mid-field woodlot and an adjacent arable field. Winter crops were grown in the fields, and their areas in different places were respectively 1.0, 1.2 and 2.0 ha. Mid-field woodlots were characterized by the following species composition of trees and shrubs:

1 - Purzec - trees on the area of about $500 \mathrm{~m}^{2}$ with birch and pine dominance

2 - Borki Siedleckie - trees on the area of about $800 \mathrm{~m}^{2}$ with birch and pine dominance

3 - Pruszyn - trees on the area of about $1200 \mathrm{~m}^{2}$ with the dominance of poplar and oak.

Samples were taken at random, separately for each environment from 10-15 points on the test area. Samples from arable fields were taken at a distance of not less than 50 meters from the edge of trees. The material was collected using Egner's stick to a depth of $15 \mathrm{~cm}$. A mixed sample was prepared from the collected material and stored in plastic bags at $0-4^{\circ} \mathrm{C}$. Immediately before starting the experiment in the laboratory, the soil was sieved and dried up to a suitable moisture content, optimal for fungal growth and limiting the development of nematodes.

Soil samples from all points were analysed to assess their granulometric composition (soil type), $\mathrm{pH}$ and organic carbon content.

Isolation of fungi. Entomopathogenic fungi were isolated from soil using two methods: the insect bait method proposed by Zimmermann (1986) and the selective medium method developed by Strasser et al. (1996) and commonly used for the isolation of entomopathogenic fungi from soil (Keller et al. 2003). The Greater Wax Moth (Galleria mellonella L.) was used as a bait insect. Ten plastic boxes with a capacity of about $200 \mathrm{ml}$ were filled with soil from each environment. Ten Galleria mellonella larvae were put in each box, a total of 100 larvae in the soil from each environment. The boxes of soil were placed in an incubator at $20-22^{\circ} \mathrm{C}$. The first mortality control was conducted 7 days after the start of the experiment and then at 3-day intervals until the death of all larvae. Dead larvae were washed in distilled water and then surface-sterilized for 30 seconds in $1 \%$ sodium hypochlorite solution. After rinsing twice in distilled water, the larvae were put on Petri dishes with moistened filter paper. The dishes with the larvae were kept at $20-22^{\circ} \mathrm{C}$ in the dark. Fungi growing on insects were transferred on standard media and then examined macroscopically. Identification of isolated fungal species was done by using standard methods described by Goettel and Inglis (1997). Fungal nomenclature follows Sung et al. (2007) and Index Fungorum (www.indexfungorum.org).

Additionally, the concentration of colony-forming units (CFU) of entomopathogenic fungi in soil environments tested was determined applying a selective medium developed by Strasser et al. (1996).

For this purpose, $2 \mathrm{~g}$ of soil were weighed out from each mixed sample originating from a given point, and then $18 \mathrm{ml}$ of distilled water were added with the addition of 0.05 Triton X-100, and the components were vigorously shaken for about 35 
seconds. Then $0.1 \mathrm{ml}$ of the soil solution was poured out and spread using a glass spatula on a selective medium in four Petri dishes which were the replicates. The dishes were placed in incubators at $22^{\circ} \mathrm{C}$ and after 8-10 days colonies of individual fungal species were counted. The results were expressed as the number of colonyforming units (CFU) of entomopathogenic fungi in $1 \mathrm{~g}$ of the soil. The selective medium used had the following composition: $10 \mathrm{~g}$ of peptone, $20 \mathrm{~g}$ of glucose and 18 $\mathrm{g}$ of agar were added to 1 litre of water. After sterilization and cooling, the following components were added to the medium: $0.6 \mathrm{~g}$ of streptomycin sulfate, $0.05 \mathrm{~g}$ of chlortetracycline, $0.05 \mathrm{~g}$ of cycloheximide and $0.1 \mathrm{~g}$ of dodine.

The results were analysed statistically by performing a 2-factorial analysis of variance. A detailed comparison of the environments was made using the Tukey's test at significance level $\alpha=0.05$.

\section{RESULTS}

The comparative study of the composition and intensity of entomopathogenic fungi in the soil from mid-field woodlots and adjacent small-scale farmlands, conducted in 2006 in three localities in the vicinity of Siedlce showed that the soil from mid-field woodlots was characterized by a richer species composition of these fungi. A total of six fungal species representing the anamorphs of Hypocreales (Ascomycota) were isolated from the soil collected from mid-field woodlots using $G$. mellonella larvae: Beauveria bassiana (Bals.-Criv.) Vuill, B. brongniartii (Sacc.) Petch, Metarhizium anisopliae (Metschn.) Sorokin, M. flavoviride W. Gams \& Rozsypal, Isaria farinosa (Holmsk,) Fr. and I. fumosorosea Wize. The presence of only three species was recorded in the farmland soil: B. bassiana, M. anisopliae and I. fumosorosea (Tabs 1 and 2). In addition, apart from typical insect-pathogenic fungi, some accompanying fungal species with unproved entomopathogenic abilities were isolated from investigated soils by means of Galleria bait method. The occurrence of fungi from the following genera was observed within this group: Aspergillus P. Micheli, Fusarium Link, Gliocladium Corda and Mucor P. Micheli ex L.

The use of selective media allowed the isolation of only three species of entomopathogenic fungi from soils of both investigated habitats, such as B. bassiana, I. fumosorosea and M. anisopliae (Tab. 3).

Four species of entomopathogenic fungi were isolated by means of bait insects from the soil samples taken from a mid-field woodlot in Purzec: B. bassiana, $M$. anisopliae, $M$. flavoviride and I. fumosorosea. The fungus B. bassiana strongly dominated in this soil, and it infected $52.7 \%$ of G. mellonella larvae and formed $4.5 \times 10^{3}$ colony-forming units (CFU) in 1 gram of soil. M. anisopliae and I. fumosorosea were of a mild intensity, infecting $6.3 \%$ and $1.1 \%$ of larvae and forming 1.7 and $1.5 \times 10^{3}$ $\mathrm{CFU} \mathrm{g}^{-1}$. Using the insect bait method only two species of entomopathogenic fungi were isolated from the adjacent farmland soil: M. anisopliae and I. fumosorosea that infected $96 \%$ and $1.0 \%$ of larvae (Tab. 1). The fungus M. anispoliae also developed the most numerous colony-forming units in the farmland soil in Purzec $\left(15.0 \times 10^{3}\right.$ $\mathrm{CFU} \mathrm{g}^{-1}$ ), and B. bassiana $1.2 \times 10^{3} \mathrm{CFU} \mathrm{g}^{-1}$ (Tab. 3). 
Table 1

Mortality of Galleria mellonella larvae (\%) caused by entomopathogenic fungi in soils from mid-field woodlots and adjacent small-scale arable fields

\begin{tabular}{|c|c|c|c|c|c|c|c|}
\hline \multirow{3}{*}{\multicolumn{2}{|c|}{ Factor of mortality }} & \multicolumn{6}{|c|}{ Locality } \\
\hline & & \multicolumn{2}{|c|}{ Purzec } & \multicolumn{2}{|c|}{ Borki Siedleckie } & \multicolumn{2}{|c|}{ Pruszyn } \\
\hline & & $\mathrm{A}^{*}$ & B & A & B & A & $\mathrm{B}$ \\
\hline \multirow{6}{*}{$\begin{array}{l}\text { Entomopathogenic } \\
\text { fungi }\end{array}$} & B. bassiana & 52.7 & 0 & 23.0 & 8.1 & 65.0 & 0 \\
\hline & B. brongniartii & 0 & 0 & $0 \mathrm{~b}$ & 0 & 3.0 & 0 \\
\hline & M. anisopliae & 6.3 & 96.0 & 71.0 & 1.0 & 1.0 & 3.0 \\
\hline & M. flavoviride & 1.1 & 0 & 0 & 0 & 0 & 0 \\
\hline & I. farinosa & $0 \mathrm{~b}$ & 0 & 0 & 0 & 1.0 & 0 \\
\hline & I. fumosorosea & 1.1 & 1.0 & 1.0 & 79.8 & 2.0 & 86.0 \\
\hline \multicolumn{2}{|l|}{ Total } & 61.2 & 97.0 & 95.0 & 88.9 & 72.0 & 89.0 \\
\hline \multirow{5}{*}{$\begin{array}{l}\text { Fungi of unproved } \\
\text { entomopathogenic } \\
\text { abilities }\end{array}$} & Mucor sp. & 5.2 & 1.0 & 0 & 5.0 & 5.0 & 0 \\
\hline & Gliocladium sp. & 3.1 & 0 & 0 & 2.0 & 1.0 & 2.0 \\
\hline & Fusarium sp. & 2.1 & 1.0 & 1.0 & 0 & 2.0 & 0 \\
\hline & Aspergillus sp. & 1.1 & 0 & 2.0 & 0 & 4.0 & 0 \\
\hline & $\begin{array}{l}\text { Unsporulated } \\
\text { mycelium }\end{array}$ & 7.4 & 1.0 & 1.0 & 1.0 & 4.0 & 4.0 \\
\hline \multicolumn{2}{|l|}{ Total } & 18.9 & 3.0 & 4.0 & 8.0 & 16.0 & 6.0 \\
\hline \multirow[t]{2}{*}{ Other causes } & Nematodes & 7.4 & 0 & 0 & 0 & 2.0 & 3.0 \\
\hline & $\begin{array}{l}\text { Unidentified } \\
\text { causes }\end{array}$ & 9.5 & 0 & 1.0 & 3.0 & 10.0 & 2.0 \\
\hline \multicolumn{2}{|l|}{ Alive specimens } & 3.1 & 0 & 0 & 0 & 0 & 0 \\
\hline
\end{tabular}

Abbreviations: * A - mid-field woodlot, B - arable field

It was found that entomopathogenic fungi invaded significantly more G. mellonella larvae and also formed more colony-forming units in the soil from the farmland than in the soil from the adjacent woodlot in this village - respectively 97.0 and $61.2 \%$, and $16.2 \times 10^{3} \mathrm{~g}^{-1}$ and $7.7 \times 10^{3} \mathrm{CFU} \mathrm{g}^{-1}$.

The soil sampled from mid-field woodlots in Borki Siedleckie was dominated by M. anisopliae which formed $11.8 \times 10^{3} \mathrm{CFU}$ in 1 gram of soil and infected $71 \%$ of larvae inserted into the soil. The fungus $B$. bassiana was also present on $23 \%$ of larvae $\left(1.8 \times 10^{3} \mathrm{CFU} \mathrm{g}^{-1}\right)$, while I. fumosorosea infected only $1 \%$ of bait insects and formed $1.2 \times 10^{3} \mathrm{CFU} \mathrm{g}^{-1}$. The same fungal species were isolated from the adjacent farmland soil but their dominance was different. The highest mortality of $G$. mellonella larvae was caused by the fungus I. fumosorosea $(79.8 \%)$, and other species such as B. bassiana and M. anisopliae invaded a small number of larvae, respectively, 8.1 and $1.0 \%$. The fungus I. fumosorosea also formed the most numerous colony-forming units in the farmland soil in Borki Siedleckie $\left(9.7 \times 10^{3} \mathrm{~g}^{-1}\right)$. It was found that entomopathogenic fungi infected more bait insect larvae and formed more colony-forming units in the woodlot soil than in the farmland soil in the village.

The soil collected from the mid-field woodlot in Pruszyn was found to have the richest entomopathogenic fungal species composition among all habitats studied. Up to five fungal species occurred in that soil: B. bassiana, B. brongniartii, M. anisopliae, I. farinosa and I. fumosorosea. The fungus B. bassiana was the most abundant among them and it infected $65.0 \%$ of bait insect larvae and formed $9.5 \times 10^{3}$ CFU in 1 gram of soil. Other species caused the mortality of individual larvae from 1.0 to $3.0 \%$, and formed a small quantity of colony-forming units from 0.3 to $2.0 \times 10^{3}$ CFU in 1 gram of soil. Only two fungal species were isolated using bait insects in the adjacent farmland soil. The fungus I. fumosorosea definitely dominated there and it 
Table 2

Mortality of Galleria mellonella larvae (\%) caused by entomopathogenic fungi in soils from mid-field woodlots and adjacent small-scale arable fields (average from three localities)

\begin{tabular}{|l|c|c|}
\hline \multirow{2}{*}{ Fungal species } & \multicolumn{2}{|c|}{ Habitat } \\
\cline { 2 - 3 } & Arable field & mid-field woodlot \\
\hline B. bassiana & 2.7 & 47.1 \\
\hline B. brongniartii & 0 & 1.0 \\
\hline M. anisopliae & 33.3 & 26.1 \\
\hline M. flavoviride & 0 & 0.4 \\
\hline I. farinosa & 0 & 0.3 \\
\hline I. fumosorosea & 55.5 & 1.4 \\
\hline Total & 91.5 & 76.3 \\
\hline
\end{tabular}

Table 3

Number of colony forming-units of entomopathogenic fungi in the soil (CFU x $\left.10^{3} \mathrm{~g}^{-1}\right)$ from mid-field woodlots and adjacent small-scale arable fields

\begin{tabular}{|c|c|c|c|c|c|c|}
\hline \multirow[t]{3}{*}{ Fungal species } & \multicolumn{6}{|c|}{ Locality } \\
\hline & \multicolumn{2}{|c|}{ Purzec } & \multicolumn{2}{|c|}{ Borki Siedleckie } & \multicolumn{2}{|c|}{ Pruszyn } \\
\hline & $\mathrm{A}^{*}$ & B & $\mathrm{A}$ & B & A & B \\
\hline B. bassiana & $4.5 \mathrm{a}^{* *}$ & $1.2 \mathrm{~b}$ & $1.8 \mathrm{~b}$ & $0.5 \mathrm{c}$ & $9.5 \mathrm{a}$ & $1.3 \mathrm{c}$ \\
\hline M. anisopliae & $1.7 \mathrm{c}$ & $15.0 \mathrm{a}$ & $11.8 \mathrm{a}$ & $1.7 \mathrm{c}$ & $0.3 \mathrm{c}$ & $8.0 \mathrm{a}$ \\
\hline I. fumosorosea & $1.5 \mathrm{c}$ & - & $1.2 \mathrm{c}$ & $9.7 \mathrm{a}$ & $2.0 \mathrm{c}$ & $13.2 \mathrm{a}$ \\
\hline Total & $7.7 b$ & $16.2 \mathrm{a}$ & $14.8 \mathrm{a}$ & $11.9 \mathrm{ab}$ & $11.8 \mathrm{~b}$ & $22.5 \mathrm{a}$ \\
\hline
\end{tabular}

Abbreviations: * A - mid-field woodlot, B - arable field; ** values in lines followed by the same letters are not significantly different

Table 4

Characteristics of soil samples

\begin{tabular}{|l|l|c|l|c|}
\hline \multicolumn{1}{|c|}{ Locality } & \multicolumn{1}{|c|}{ Habitat } & $\begin{array}{c}\text { Soil } \mathrm{pH} \\
(\mathrm{pH} \mathrm{w} \mathrm{mol} \\
\left.\times \mathrm{dm}^{3} \mathrm{KCL}\right)\end{array}$ & \multicolumn{1}{c|}{ Soil type } & $\begin{array}{c}\text { Organic } \\
\text { carbon } \\
\text { content }(\%)\end{array}$ \\
\hline \multirow{2}{*}{ Borki Siedleckie } & arable field & 5.43 & loamy sand & 0.851 \\
\cline { 2 - 5 } & mid-field woodlots & 4.78 & sandy loam & 2.477 \\
\hline \multirow{2}{*}{ Purzec } & arable field & 4.72 & weakly loamy sand & 0.686 \\
\cline { 2 - 5 } & mid-field woodlots & 4.60 & weakly loamy sand & 1.114 \\
\hline Pruszyn & arable field & 4.49 & weakly loamy sand & 0.538 \\
\cline { 2 - 5 } & mid-field woodlots & 4.64 & loamy sand & 3.335 \\
\hline
\end{tabular}

caused the death of $86.0 \%$ of larvae. Moreover, the presence of $M$. anisopliae was observed on $3.0 \%$ of $G$. mellonella larvae (Tab. 1). The fungus I. fumosorosea also formed by far the most numerous colony-forming units in the soil $\left(13.2 \times 10^{3} \mathrm{~g}^{-1}\right)$. $M$. anisopliae was also in a relatively high density $\left(8.0 \times 10^{3} \mathrm{~g}^{-1}\right)$, while B. bassiana formed the fewest colony-forming units (Tab.3).

Comparing the occurrence of entomopathogenic fungi in the soil from woodlots to their neighbouring farmlands in the three villages studied, we can conclude that $B$. bassiana infected most bait insect larvae in woodlot soil (a total of $47.1 \%$ of larvae) (Tab. 2). This fungus also formed the most numerous colony-forming units in two of the three mid-field woodlots studied. $M$. anisopliae was another species which infected most $G$. mellonella larvae in the soil under trees $(26.1 \%)$. The fungus formed by far the most numerous colony-forming units in the woodlot soil in Borki Siedleckie. 


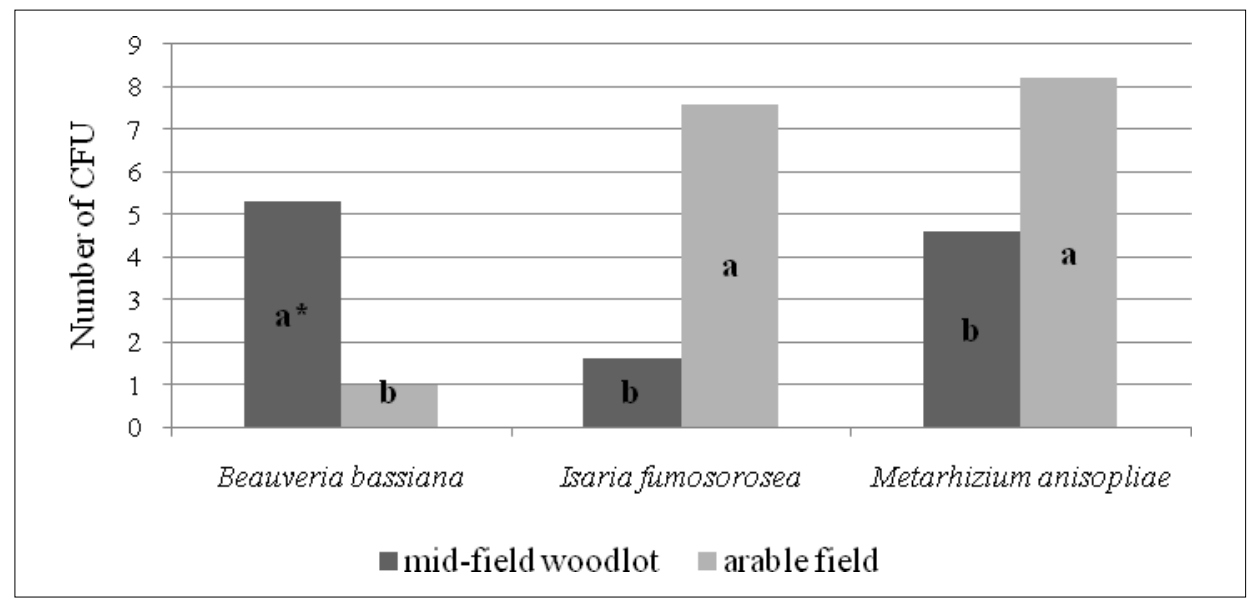

Fig. 1. Number of colony forming-units of entomopathogenic fungi in the soil (CFU x $\left.10^{3} \mathrm{~g}^{-1}\right)$ from mid-field woodlots and adjacent small-scale arable fields (average from three localities) * values followed by the same letters are not significantly different

Given the presence of entomopathogenic fungi in the farmland soil in the three test places together, it was found that I. fumosorosea was dominant in the soil from the two arable fields. In the farmland soil from Borki Siedleckie and Pruszyn, the fungus infected more G. mellonella larvae and formed significantly more CFUs than the other species of fungi. M. anisopliae was the second most frequently isolated farmland species. This fungus definitely dominated bait insect larvae in the farmland soil in Purzec, and it formed the most numerous colony-forming units in 1 gram of soil (Tabs 1 and 3).

Figure 1 illustrates the difference in density of colony-forming units of entomopathogenic fungi in soils from arable fields and adjacent woodlots. It was found that entomopathogenic fungi together formed more colony-forming units in the soil from arable fields than that of neighbouring mid-field woodlots. The fungus B. bassiana formed significantly more colony-forming units (CFU) in the soil from mid-field woodlots than that of farmland in the localities studied, whereas the trend was the opposite in the case of I. fumosorosea and M. anisopliae (Fig. 1).

\section{DISCUSSION}

Transformation of landscape relations, especially deforestation for agricultural production and the simplification of species composition and the age structure of forest stands lasting for at least two centuries are not conducive to the maintenance of species-rich groups of insects and their pathogens in anthropogenically transformed environments (Altieri 1999). For these reasons, unfarmed parts of natural vegetation clusters, marginal among arable fields, (field margins, roadsides, swamps), water tanks, as well as trees and shrubs introduced in strips on small areas of land become 
very important for the preservation of the biotic assemblages (Bałazy, Cysewski 2003). These habitats are specific refugia for flora and fauna which are not present in farmland (Marshall, Monen 2002), and are the ideal place for many wintering species of arthropods.

It was found that in the area of semi-natural strips with a width of 3 to $6 \mathrm{~m}$ on the edges of fields, the number of living species of arthropods is more than two times higher than in their neighbouring farmland (Meek et al. 2002). According to Karg et al. (2003), the biomass of dipteran larvae in the soil from mid-field woodlots in Turew was 80 -fold higher than in the soil from the adjacent field, and the total biomass of macrofauna was 90 -fold higher. With regard to mesofauna, the biomass was 9-fold higher in the shelterbelt soil than in the soil from the adjacent field.

The species richness of arthropods, especially insects, in the area of mid-field woodlots undoubtedly affects the species diversity of their natural enemies, including entomopathogenic fungi. This was confirmed in our research. The species composition of entomopathogenic fungi was far richer in the soil from mid-field woodlots than in the soil from neighbouring farmlands. In the soil collected from woodlots, a total of six fungal species were isolated using G. mellonella larvae: $B$. bassiana, B. brongniartii, M. anisopliae, M. flavoviride, I. farinosa and I. fumosorosea. The presence of only three species was reported in the soil from arable fields: B. bassiana, M. anisopliae and I. fumosorosea. Chandler et al. (1997), Meyling and Eilenberg (2006) and Tkaczuk (2008) also draw attention to the richer species composition of entomopathogenic fungi in soils from shelterbelts surrounding arable fields, and emphasize the important role of natural habitats as specific refugia for the survival of these fungi in agrocenoses. Mayling (2005) showed, moreover, that shelterbelts around arable fields are also reservoirs for a variety of phylogenetic lines of the fungus $B$. bassiana. Studying strains of this species, obtained from a field of about 28 ha and an adjacent belt of trees with a total area of only 0.44 ha, he recorded a significantly higher genetic diversity of fungal isolates from under the trees than from the field where there was, in principle, only one genetic group of $B$. bassiana. According to the above-mentioned author, this fact confirms the important role of semi-natural habitats as a source of biodiversity of entomopathogenic fungi in agricultural landscape.

B. bassiana was the species of fungus which infected most bait insect larvae and formed the biggest number of CFUs in the soil from mid-field woodlots studied. This fungus is cited as co-dominant with I. fumosorosea in soils of semi-natural habitats in Poland (Tkaczuk 2008). According to Vannninen (1995) and Steenberg (1995), B. bassiana is characteristic of natural habitats (mid-field woodlots, shelterbelts) and is less common in agricultural soils. One of the concepts explains the dominance of $B$. bassiana in soils from mid-field woodlots which, as revealed by the study (Tab.4) are much richer in organic matter than farmland soils, is the ability of this fungus to grow in the saprophagous phase (Müller-Kögler, Zimmermann 1986; Storey et al. 1989). B. bassiana definitely dominates in soil and forest litter, i.e. the agricultural landscape environments that are probably the most similar to woodlots. It should also be noted that the survival of entomopathogenic fungi in soil largely depends on the stability of environmental conditions and the related continuous or at least frequent presence of potential insect hosts. In its 
development cycle, the species $B$. bassiana seems to use a strategy that Ewald (1983, 1995) has called "sit and wait", which means that the population growth and survival of the fungus in soil depend mainly on periodical infections of hosts, and factors limiting the population of hosts seem to substantially affect the survival of B. bassiana in the soil environment. Wojciechowska et al. (1977), Daoust \& Pereira (1986) and Steenberg (1995) showed that the constant presence of arthropods in soil as potential hosts for $B$. bassiana has a significant impact on the survival of the species.

Given the presence of entomopathogenic fungi in the farmland soil in the three villages studied, it was found that I. fumosorosea was dominant in the soil from two arable fields, and $M$. anisopliae in one of the farmlands. As demonstrated by the analyses, all soils from the three fields studied were sandy loam (Tab.4). According to Tkaczuk (2008) the presence of entomopathogenic fungi in farmland soils in Poland was dependent on soil type. Sandy soils were dominated by I. fumosorosea and M. anisopliae, while I. fumosorosea, M. anisopliae and B. bassiana were of similar intensity in clay soils, whereas B. bassiana and then $M$. anisopliae were by far the most common in organic soils. The dominance of I. fumosorosea and M. anisopliae in farmland sandy soils is confirmed by earlier studies conducted by Tkaczuk \& Miętkiewski (1996) and Kleespies et al. (1989). These authors also report a very low intensity of $B$. bassiana in these soils.

Examining the concentration of colony-forming units of entomopathogenic fungi in the soil from large-scale fields and neighbouring strips of trees in Austria and Poland, Tkaczuk (2008) showed that these fungi formed more colony-forming units in the soil under shelterbelts. In our study, in the case of soil from two of the three pairs of test environments (field-woodlots), there was a greater concentration of CFUs of entomopathogenic fungi in the farmland soil. The differences may be due to the fact that our study was conducted in small-scale fields (up to 2 ha) where farmers use minimal chemical protection, while research conducted by Tkaczuk (2008) related to fields with an area of more than 5 ha where extensive chemical treatments were applied (this is particularly true of research conducted in Austria), which could adversely affect the development of entomopathogenic fungi in the soil. According to Karg and Bałazy (2009), the simplification of the structure of crops, chemical control of pests and cyclically repeated tillage practices aimed at the intensification of crops directly or indirectly eliminate pathogens of arthropods, on a par with parasites and predators, as trophic groups with specific environmental and nutritional requirements. However, most of them are characterized by a high adaptability to adverse environmental conditions, and usually a high reproductive and migration potential, they can quickly colonize the environments from which they have been eliminated as a result of agricultural practices, as long as there are suitable refugia around the fields. Among such refugia can be undoubtedly small mid-field woodlots which are characteristic of the agricultural landscape in the Nizina Południowopodlaska lowland where this study was conducted. According to Marshall \& Monen (2000) and Meek et al. (2002), especially the transition area (ecotone) between a cultivated field and a stable semi-natural environment is a habitat for species characteristic of both environments, and it makes it possible to enrich depleted entomofauna of farmland. 


\section{CONCLUSIONS}

The occurrence, development and pathogenicity of entomopathogenic fungi in soil are conditioned by a number of biotic and abiotic factors in the environment, as well as the agricultural and non-agricultural human activity. In agricultural landscape, arable fields are surrounded by semi-natural habitats such as mid-field woodlots which are specific refugia for flora and fauna not present in arable fields. Our comparative study showed that the soil from mid-field woodlots was characterized by a richer species composition of entomopathogenic fungi than of adjacent arable fields. A total of six fungal species representing the anamorphs of Hypocreales (Ascomycota) were isolated from the soil collected from mid-field woodlots: B. bassiana, B. brongniartii, M. anisopliae, M. flavoviride, I. farinosa and I. fumosorosea. The presence of only three species was reported in the farmland soil: B. bassiana, M. anisopliae and I. fumosorosea. This fact confirms the important role of semi-natural habitats as a source of biodiversity of entomopathogenic fungi in agricultural landscape.

Aknowledgements. The study was supported by the Scientific and Technological Cooperation Project: Austria-Poland (PL 12/2006); University of Natural Resources and Life Sciences, Vienna (Austria) and Siedlce University of Natural Sciences and Humanities (Poland).

\section{REFERENCES}

Altieri M.A. 1999. The ecological role of biodiversity in agroecosystems. Agric. Ecosyst. Environ. 74: $19-31$.

Bajan C., Kmitowa K., Mierzejewska E., Popowska-Nowak E., Miętkiewski R., Górski R., Miętkiewska Z., Głowacka B. 1995. Występowanie grzybów owadobójczych w ściółce i glebie borów sosnowych w gradiencie skażenia środowiska leśnego. (Occurrence of entomopathogenic fungi in litter and soil of pine forest in a gradient of forest environmental contamination). Prace IBL. ser. B, $24: 87-97$.

Bałazy S. 2007. Grzyby entomopatogeniczne i ich znaczenie dla programów ochrony roślin (Entomopathogenic fungi and their significance for plant protection programmes). (In:) S. Bałazy, A. Gmiąt (eds). Ochrona środowiska rolniczego w świetle programów rolno-środowiskowy Unii Europejskiej, Brzesko-Poznań-Turew: 118-126.

Bałazy S., Cysewski R. 2003. Różnorodność grzybów entomopatogenicznych na obszarach chronionych. (Diversity of entomopathogenic fungi in protected areas) (In:) K. Gwoździński (ed.). Bory Tucholskie. II. Zasoby i ich ochrona. Wyd. Uniwersytetu Łódzkiego, Łódź : 113-142.

Bidochka M.J., Kasperski J.E. Wild G.A.M. 1998. Occurrence of the entomopathogenic fungi Metarhizium anisopliae and Beauveria bassiana in soils from temperate and near-northern habitats. Can. J. Bot. 76: 1198-1204.

Chandler D., Hay D., Reid A.P., 1997. Sampling and occurrence of entomopathogenic fungi and nematodes in UK soils. Appl. Soil Ecol. 5: 133-141.

Daoust R.A., Pereira R.M. 1986. Survival of Beauveria bassiana (Deuteromycetes: Moniliales) conidia on cadavers of cowpea pests stored outdoors and in laboratory in Brazil. Environ. Entomol. 15: 642-647.

Ewald P.W. 1983. Host parasite relations, vectors, and the evolution of disease severity. Annual Review of Ecology and Systematics 14: 465-485.

Ewald P.W. 1995. The evolution of virulence: a unifying link between parasitology and ecology. J. Parasit., 81: 659-669.

Ferron P. 1981. Pest control by the fungi Beauveria and Metarhizium. (In:) H.D. Burges (ed.). Microbial control of pest and plant diseases, 1970-1980., Academic Press, London: 465-482. 
Gaugler R. 1988. Ecological consideration in the biological control of soil-inhabiting insects with entomopathogenic nematodes. Agric. Ecosyst. Environ.24: 351-361.

Goetel M.S., Inglis G.D. 1997. Fungi: Hyphomycetes. (In:) Manual of Techniques in Insect Pathology. Academic Press, London: 213- 249.

Ignoffo C.M., Garcia C., Hostetter D.L., Pinnell R.E. 1978. Stability of conidia of an entomopathogenic fungus, Nomuraea rileyi, in and on soil. Environ. Entomol. 7: 724-727.

Karg J. 1989. Zróżnicowanie liczebności i biomasy owadów latających krajobrazu rolniczego zachodniej Wielkopolski. (Differentiation of abundance and biomass of flying insects of Western Wielkopolska agricultural landscape). Rocz. Akad. Rol. Poznań 188: 1-78.

Karg J., Bałazy S. 2009. Wpływ struktury krajobrazu na występowanie agrofagów i ich antagonistów w uprawach rolniczych. (Effect of landscape structure on the occurrence of agrophagous pests and their antagonists). Prog. Plant Prot./Post. Ochr. Roślin 49 (3): 115-134.

Karg J., Kajak A., Ryszkowski L. 2003. Impact of young shelterbelts on organic matter content and development of microbial and fauna communities of adjacent fields. Pol. J. Ecol. 51 (3): 283-290.

Keller S., Kessler P., Schweizer C. 2003. Distribution of insect pathogenic soil fungi in Switzerland with special reference to Beauveria brongniartii and Metarhizium anisopliae. Biocontrol 48: 307-319.

Kleespies R., Bathon H., Zimmermann G. 1989. Untersuchungen zum natürlichen Vorkommen von entomopathogenen Pilzen und Nematoden in verschiedenen Böden in der Umgebung von Darmstadt. Gesunde Pflanzen 41: 350-355.

Klingen I., Eilenberg J., Meadow R. 2002. Effects of farming system, field margins and bait insect on the occurrence of insect pathogenic fungi in soils. Agric. Ecosyst. Environ. 91: 191-198.

Marshal E.J.P., Moonen A.C. 2002. Field margins in northern Europe: their functions and interactions with agriculture. Agric. Ecosyst. Environ. 89: 5-21.

Meek B., Loxton D., Sparks T., Pywell R., Picket H., Nowakowski M. 2002. The effect of arable field margin composition on invertebrate biodiversity. Biol. Conser. 106: 259-271.

Meyling N.V. 2005. Population ecology and genetic diversity of entomopathogenic fungi (Ascomycota: Hyphocreales) in agroecosystems and field margins. Ph.D. Thesis, The Royal Veterinary and Agricultural University, Copenhagen

Meyling N.V., Eilenberg J. 2006. Occurrence and distribution of soil borne entomopathogenic fungi within a single organic agroecosystem. Agric. Ecosyst. Environ. 113: 336-341.

Miętkiewski R., Tkaczuk C., Żurek M., L.P.S. Van der Geest 1994. Temperature requirements of four entomopathogenic fungi. Acta Mycol. 29 (1): 109-120.

Müller-Kögler E., Zimmermann G. 1986. Zur Lebensdauer von Beauveria bassiana in kontaminiertem Boden unter Freiland- und Laboratoriumsbedungungen. Entomophaga 31: 285-292.

Ryszkowski L. 1985. Impoveriso agriculthment of soil fauna due the agriculture. (In:) J.H. Cooley (ed.). Soil ecology and management. Intecol Bull., Athens-USA 12: 6-17.

Ryszkowski L., Karg J. 1991. The effect of the structure of agricultural landscape on biomas of insect of the above-ground fauna. Ekol. Pol. 39 (2): 171-179.

Steenberg T. 1995. Natural occurrence of Beauveria bassiana (Bals,) Vuill. with focus on infectivity to Sitona species and other insects in Lucerne. Ph.D. Thesis, The Royal Veterinary and Agricultural University, Copenhagen.

Storey G.K., Gardner W.A., Tollner E.W. 1989. Penetration and persistence of commercially formulated Beauveria bassiana conidia in a loam and peat soil. J. Invertebr. Pathol. 55: 417-427.

Strasser H., Forrer A., Schinner F. 1996. Development of media fort he selective isolation and maintenance of virulence of Beauveria brongniartii. (In:) T.A. Jackson, T.R. Glare (eds). Microbial control of soil dwelling pests. AgResearch, Lincoln, New Zeland: 125-130.

Sung G.H., Hywel-Jones N.L., Sung J.M., Luangsa-ard J.J., Shrestha B., Spatafora J.W. 2007. Phylogenetic classification of Cordyceps and the clavicipitaceous fungi. Stud. Mycol. 57: 5-59.

Tkaczuk C. 2008. Występowanie i potencjał infekcyjny grzybów owadobójczych w glebach agrocenoz i środowisk seminaturalnych w krajobrazie rolniczym. (Occurrence and infective potential of entomopathogenic fungi in the soils of agrocenoses and semi-natural habitats in agricultural landscape). Rozprawa naukowa nr 94. Wyd. Akademii Podlaskiej, Siedlce, 160 pp.

Tkaczuk C., Miętkiewski R. 1996. Occurrence of entomopathogenic fungi in different kinds of soil. Rocz. Nauk Rol., Seria E 25(1/2): 44-48.

Vänninen I. 1995. Distribution and occurrence of four entomopathogenic fungi in Finland: Effect of geographical location, habitat type and soil type. Mycol. Res. 100: 93-101. 
Wojciechowska M., Kmitowa K., Bajan C. 1977. The effect of carbamidae herbicides linuron and monolinuron on the three of species of entomopathogenic fungi. II Pot experiments. Pol. Ecol. Stud. 3 (2): 43-57.

Zimmermann G. 1986. Galleria bait method for detection of entomopathogenic fungi in soil. J. App. Entomol. 2: 213-215.

\section{Występowanie grzybów entomopatogenicznych w glebach z zadrzewień śródpolnych i sąsiadujących z nimi małoobszarowych pól uprawnych}

\section{Streszczenie}

Celem podjętych badań było porównanie składu gatunkowego i nasilenia występowania grzybów entomopatogeniczych w glebach z zadrzewień śródpolnych i sąsiadujących z nimi pól uprawnych. Materiał do badań stanowiły próby gleby pobrane w trzech miejscowościach w okolicach Siedlce $\mathrm{z}$ dwóch środowisk: zadrzewienia śródpolnego i sąsiadującego $\mathrm{z}$ nimi małoobszarowego pola uprawnego. Grzyby owadobójcze izolowano z gleby stosując metodę owadów pułapkowych (z użyciem larw Galleria mellonella) oraz podłoże selektywne. Przeprowadzone badania porównawcze wykazały, że gleby spod zadrzewień śródpolnych charakteryzowały się bogatszym składem gatunkowym tych grzybów. Z gleby pobranej spod zadrzewień śródpolnych na larwy $G$. mellonella wyizolowano w sumie sześć gatunków grzybów, były to: B. bassiana, B. brongniartii, M. anisopliae, M. flavoviride, I. farinosa i I. fumosorosea. W glebie z pól odnotowano obecność tylko trzech gatunków: B. bassiana, M. anisopliae i I. fumosorosea . Fakt ten potwierdza istotną rolę środowisk seminaturalnych jako źródła bioróżnorodności grzybów owadobójczych w krajobrazie rolniczym. Stwierdzono że, grzyby entomopatogeniczne łącznie tworzyły więcej jednostek infekcyjnych (CFU) w glebie z pól uprawnych niż sąsiadujących z nimi zadrzewień śródpolnych. Stwierdzono, że grzyb B. bassiana zainfekował więcej larw owada pułapkowego i tworzył istotnie więcej jednostek infekcyjnych w glebach z zadrzewień śródpolnych niż pól w badanych miejscowościach, natomiast w przypadku I. fumosorosea i M. anisopliae odnotowano tendencję odwrotną. Biorąc pod uwagę występowanie grzybów entomopatogennych w glebie z pól uprawnych w trzech badanych miejscowościach łącznie, stwierdzono, że w glebie z dwóch pól uprawnych dominował I. fumosorosea. W glebach tych zainfekował on więcej larw G. mellonella i tworzył istotnie więcej jednostek CFU niż pozostałe gatunki grzybów. Drugim najczęściej izolowanym gatunkiem z pól uprawnych był M. anisopliae. 